\section{Seasonal Applications of a Pyraclostrobin and Boscalid Mixture Do Not Impact Same-year Peach Fruit Quality Attributes}

\author{
G. Schnabel ${ }^{1,3}$ and C.H. Crisosto ${ }^{2}$
}

Additional Index words. Prunus persica, scab, Pristine, greening effect, fungicide, firmness

Summary. Quinone outside inhibitor (QoI) fungicides can improve the yield and quality of cereal crops in the absence of disease pressure through the so called "greening effect," but little is known about the potential beneficial effects on deciduous tree fruit crops. In a multiyear and multicultivar study carried out in South Carolina (2005 and 2006) and California (2006), we examined the potential influence of the QoI fungicide pyraclostrobin on antioxidant activity and commercially important peach (Prunus persica) fruit quality attributes, including fruit size, coloration, firmness, soluble solids concentration, and yield.

Experimental orchards were sprayed according to commercial guidelines to manage insect pests and diseases. A pyraclostrobin + boscalid mixture was applied up to five times per season starting 1 week after the physiological stage of "shuck off" until 1 to 2 weeks before harvest. Fruit size was measured weekly between "shuck off" and harvest, whereas the other fruit quality attributes were determined at harvest. Results indicate no consistent impact of the pyraclostrobin + boscalid mixture on same-year fruit size development or other fruit quality attributes in orchards with no or very little disease pressure. To our knowledge, this is the first in-depth evaluation of the potential effects of a QoI fungicide on commercially important tree fruit quality attributes.

A pplications of the quinone outside inhibitor (QoI) fungicides azoxystrobin, kresoximmethyl, trifloxystrobin, picoxystrobin, or pyraclostrobin can increase yield and quality of cereal crops, likely due to improved disease control (Ammermann et al., 2000; Godwin et al., 2000; Jones and Bryson, 1998; Margot et al., 1998; Noon, 1997). However, in some crops, a yield increase was observed in the absence of disease symptoms. For example, an increase in yield in winter wheat (Triticum aestivum) showing no apparent disease symptoms was observed when azoxystrobin was applied (Jones

Technical Contribution No. 5324 of the Clemson University Experiment Station. This material is based upon work supported by the CSREES/USDA under project number SC-1000642.

We thank Karen Bryson, Sam Hudson, Billy Newall, David Garner, and Vanessa Bremer for technical assistance, Kerik Cox (Cornell University) and William Bridges (Clemson University) for helping with the statistical analysis, and BASF Corporation for financial support of this study.

${ }^{1}$ Department of Entomology, Soils, and Plant Sciences, Clemson University, 120 Long Hall, Clemson, SC 29634

${ }^{2}$ Department of Plant Sciences, University of California, Davis, Davis, California. Located at Kearney Agricultural Center, 9240 South Riverbend Ave. Parlier, CA 93648

${ }^{3}$ Corresponding author. E-mail: schnabe@clemson. edu.
Some contain pyraclostrobin as the sole fungicidal material (e.g., Cabrio EG; BASF Corp., Research Triangle Park, NC) and some are marketed as a premixture of pyraclostrobin + boscalid (Pristine, BASF). The pyraclostrobin + boscalid mixture is currently the only formulation containing pyraclostrobin registered for disease control in stone fruit in the United States.

Most yield and quality studies with QoI fungicides have focused on wheat or barley (Hordeum vulgare). However, more studies are emerging that document disease control and additional benefits in other crops, such as rice (Oryza sativa), potato (Solanum tuberosum), and tomato (Solanum lycopersicum) (Harrison and Tedford, 1999; Siviero and Azzaro, 2001; Stevenson et al., 1999). Reports on fruit are rare and it is not clear if the observed increase in total yield or percentage of marketable fruit was a result of improved disease control or the "greening effect" (Ammermann et al., 2000; Heaney and Knight, 1994). The goal of this study was to investigate possible same-year beneficial effects of the QoI fungicide pyraclostrobin in the absence of disease pressure on antioxidant activity and commercially important peach fruit quality attributes, including fruit size, coloration, firmness, soluble solids concentration, and yield.

\section{Materials and methods}

ORCHARD PREPARATION AND Fungicide Resistance Action Committee (FRAC) code 11 due to their identical modes of action. They bind to the ubihydroquinone reduction site, the $\mathrm{Q}_{\mathrm{o}}$-site of complex $b c_{1}$, thus inhibiting electron transfer between cytochrome $b$ and cytochrome $c_{1}$ in the respiratory chain (Becker et al., 1981; Von Jagow and Link, 1986). Pyraclostrobin is available in various formulations.
EXPERIMENTAL SETUP. Experimental peach orchards in South Carolina and California were used in this study, and pests and diseases were managed according to grower standards. The South Carolina orchards were established in 1995 at the Clemson University Musser Fruit Research Farm at Seneca. Orchards with the early

\begin{tabular}{llll}
\hline $\begin{array}{l}\text { Units } \\
\text { To convert U.S. to SI, } \\
\text { multiply by }\end{array}$ & U.S. unit & SI unit & $\begin{array}{l}\text { To convert SI to U.S., } \\
\text { multiply by }\end{array}$ \\
\hline 0.3048 & $\mathrm{ft}$ & $\mathrm{m}$ & 3.2808 \\
3.7854 & $\mathrm{gal}$ & $\mathrm{L}$ & 0.2642 \\
9.3540 & $\mathrm{gal} / \mathrm{acre}$ & $\mathrm{L} \cdot \mathrm{ha}^{-1}$ & 0.1069 \\
25.4 & inch $(\mathrm{es})$ & $\mathrm{mm}$ & 0.0394 \\
0.4536 & $\mathrm{lb}$ & $\mathrm{kg}$ & 2.2046 \\
70.0532 & $\mathrm{oz} / \mathrm{acre}$ & $\mathrm{g} \cdot \mathrm{ha}^{-1}$ & 0.0143 \\
1 & $\mathrm{ppm}$ & $\mu \mathrm{\mu g} \cdot \mathrm{g}^{-1}$ & 1 \\
6.8948 & $\mathrm{psi}$ & $\mathrm{kPa}$ & 0.1450 \\
$\left({ }^{\circ} \mathrm{F}-32\right) \div 1.8$ & ${ }^{\circ} \mathrm{F}$ & ${ }^{\circ} \mathrm{C}$ & $\left(1.8 \times{ }^{\circ} \mathrm{C}\right)+32$ \\
& & &
\end{tabular}



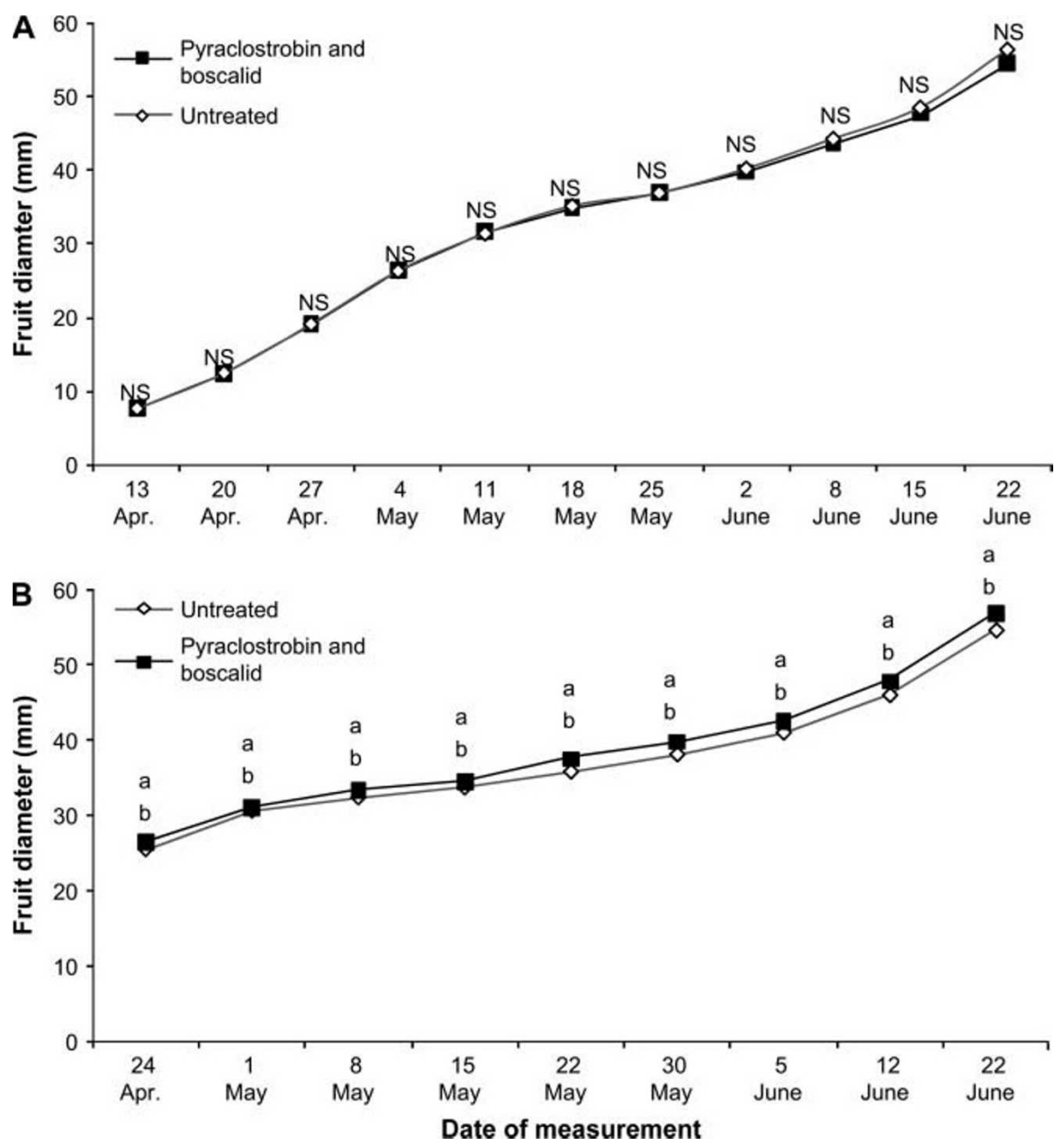

Fig. 1. Influence of seasonal pyraclostrobin + boscalid applications on mean fruit size of 'Coronet' peaches in experimental years (A) 2005 and (B) 2006.

Pyraclostrobin + boscalid mixture was applied four (2005) and five (2006) times in 2 -week intervals between the phenological stage of "shuck split" and 1 to 2 weeks before harvest. Letters above mean values indicate significances between treatments at $P<0.05 ; \mathrm{NS}=$ nonsignificant $(1 \mathrm{~mm}=0.0394$ inch $)$.

ripening cultivar Coronet and the midseason cultivar Contender were used for this study. 'Contender' peaches ripen $\approx 3$ weeks later than the 'Coronet' peaches. All trees were planted on 'Guardian' ${ }^{\circledR}$ rootstock, and spacing between trees and rows was $6 \mathrm{~m}$. Insecticides, fungicides, and herbicides were applied to all trees according to recommendations of the Southeastern Peach Spray Guide (Brannen et al., 2005). Thinning was conducted by hand twice within 2 weeks after the phenological stage of "shuck split" to ensure even thinning among trees. The California orchards were located at the University of California, Kearney Agricultural Center at Parlier. The nectarine cultivar May Glo and the peach cultivar O'Henry were used for this study. All experimental trees (including the
Protection, Greensboro, NC) and phosmet (Imidan 70WSB; Gowan, Yuma, AZ) on 8 Apr.; captan (Captec 4L; Micro Flo, Memphis, TN) on 14 Apr.; captan and phosmet on 25 Apr., 6 May, 18 May, and 4 June; micronized sulfur (Microthiol Disperss 80DF; Ceraxagri, Philadelphia) and phosmet on 16 June; captan and phosmet on 30 June ('Contender' only), and propiconazole (Orbit 3.6EC; Syngenta Crop Protection) on 1 July ('Coronet' only). In 2006, the "untreated" program consisted of the following fungicide and insecticide applications: captan and phosmet on 3 Apr.; chlorothalonil (Bravo Weather Stik 6F; Syngenta Crop Protection) and phosmet on 10 Apr.; micronized sulfur and phosmet on 20 Apr.; captan and phosmet on 3 May; micronized sulfur and phosmet on 25 May, 8 May, and 22 June; fenbuconazole (Indar 75WSP; Rohm and Haas, Philadelphia) on 22 and 29 June; and captan on 6 July ('Contender' only). All fungicides and insecticides were applied with an air-blast sprayer at label rates using $\approx 200 \mathrm{gal} /$ acre water. The second fungicide program consisted of the "untreated" program plus applications of a pyraclostrobin + boscalid mixture (Pristine) applied at $14.5 \mathrm{oz} /$ acre formulated product. In 2005, peaches were sprayed with a pyraclostrobin + boscalid mixture on 15 Apr., 29 Apr., 31 May ('Coronet' only), 16 June, I July ('Contender' only), and 12 July ('Contender' only). In 2006, 'Coronet' and 'Contender' peaches were sprayed with pyraclostrobin + boscalid on 25 Apr., 9 May, 23 May, 6 June, and 20 June. Trees were sprayed to runoff ( $1.5 \mathrm{gal} / \mathrm{tree})$ at 200 psi pressure using a handgun sprayer.

In California, the pyraclostrobin + boscalid mixture was applied at different physiological stages using 12 'May Glo' or 18 'O'Henry' single-tree replications in a randomized complete block design. 'O'Henry' received the following five treatments: 1) one spray during bloom only (S-1);2) two sprays during pit hardening only (S-2); 3) two preharvest sprays only, $\approx 14$ and $7 \mathrm{~d}$ before predicted harvest (S-3); 4) one spray at bloom plus two sprays during pit hardening plus two preharvest sprays $\approx 14$ and $7 \mathrm{~d}$ before predicted harvest (S-1-2-3); and 5) an untreated control. 'May Glo' received only two treatments: 1) S-3 as above, and 2) an untreated control because 

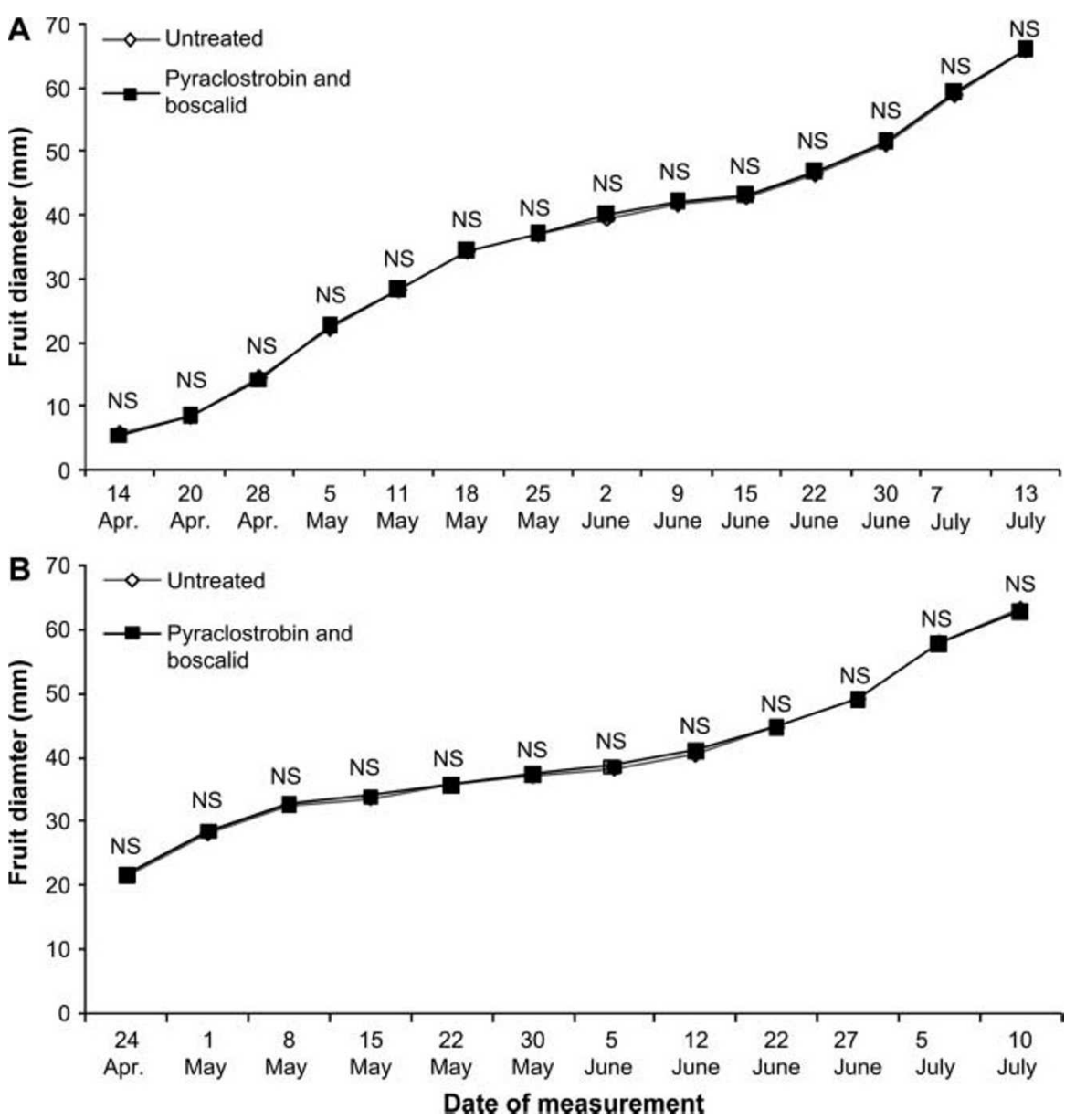

Fig. 2. Influence of seasonal pyraclostrobin + boscalid applications on mean fruit size of 'Contender' peaches in experimental years (A) 2005 and (B) 2006. Pyraclostrobin + boscalid mixture was applied in 2 -week intervals between the phenological stage of "shuck split" and 1 to 2 weeks before harvest; NS = nonsignificant at $P<0.05(1 \mathrm{~mm}=0.0394$ inch $)$.

of its short fruit growth period. Similar to the South Carolina treatments, the rate of pyraclostrobin + boscalid application was $14.5 \mathrm{oz} /$ acre formulated product (Pristine), which is the current maximum label rate. Trees were sprayed with $200 \mathrm{gal} / \mathrm{acre}$ water $(\approx 0.5$ gal per side of a tree) using an airblast sprayer.

FRUIT SIZE AND WEIGHT MEASUREMENTS. The development of fruit size over the course of the season and the weight of mature fruit at harvest were determined for both treatments. For 'Coronet' and 'Contender' 10 2-year-old branches were selected from each experimental tree and one fruit per branch of about equal size and shape was used weekly to monitor fruit size over the course of the growing season. For 'May Glo' and 'O'Henry', six fruit from the middle portion of the canopy (within hand's reach) of each tree were marked and their diameters were measured every 3 to $7 \mathrm{~d}$ with a digital caliper starting from 1 week after "shuck off" to l week before harvest. Measurements were conducted from a premarked dot located midcheek of each selected fruit to the corresponding point on the opposite side. The dots were $5 \mathrm{~mm}$ in diameter and were carefully drawn using a waterproof black-ink marker with a chisel tip. Dots were redrawn over the course of the season when necessary. Each cultivar was harvested twice, and for each harvest, the weight of 50 randomly selected, commercially mature fruit was determined using a digital scale (model PM 4000; Mettler Instruments, Hightstown, NJ). 'Coronet' fruit were harvested on 27 and 30 June 2005, and 26 June and 3 July 2006. 'Contender' fruit were harvested on 19 and 22 July 2005, and 14 and 18 July 2006. 'May Glo' and 'O'Henry' were harvested on 30 May and 13 Aug., respectively.

FRUIT COLOR AND MATURITY evaluations. In South Carolina, at each harvest date, the same fruit used for weight evaluation (50 fruit) were used for color and maturity ratings. Each fruit was rated visually for surface red color on a 1 to 4 scale where 1 $=0 \%$ to $25 \%, 2=26 \%$ to $50 \%, 3=51 \%$ to $75 \%$, and $4=76 \%$ to $100 \%$. The same person sorted by color at each harvest. A 10-fruit subsample of the 50 -fruit sample was subsequently evaluated for background color using standard color reference cards (Delwiche and Baumgardner, 1985). This subsample was a proportional representation of the 50-fruit sample based on the color categories represented. For example, if a 50-fruit sample had $5,15,20$, and 10 fruit in color categories $1,2,3$, and 4 , respectively, one, three, four, and two fruit, respectively, were randomly selected from the four color categories for maturity evaluations. Background color reference cards use a l (mostly green) to 6 (mostly yellow) scale, where a higher number indicates greater maturity. The total number of fruit in each color category was determined for each 50-fruit sample (red color) and 10-fruit subsample (background color). A second 10-fruit subsample was selected as described above and used for maturity evaluations.

In California, fruit quality attributes including skin color, firmness, soluble solids concentration (SSC), titratable acidity (TA), and antioxidant activity were measured according to a previously published protocol (Brand-Williams et al., 1995; Crisosto et al., 1994). The percentage of the fruit's skin covered with red pigmentation (blush) was visually estimated. Next, a small section of skin was removed with a peeler from cheeks, tip, suture, and shoulder. Firmness was then measured at all five peeled points using a U.C. firmness tester (Western Industrial Supply, San Francisco, CA) or an Effigi penetrometer (model FT327; McCormick Fruit Tech, Yakima, WA) equipped with a 5/16-inch tip. After weight and firmness determinations, longitudinal slices (from shoulder to tip) were cut each day of evaluation for determination of SSC and TA, and analysis of antioxidants. Ten slices per replication-treatment (from different 


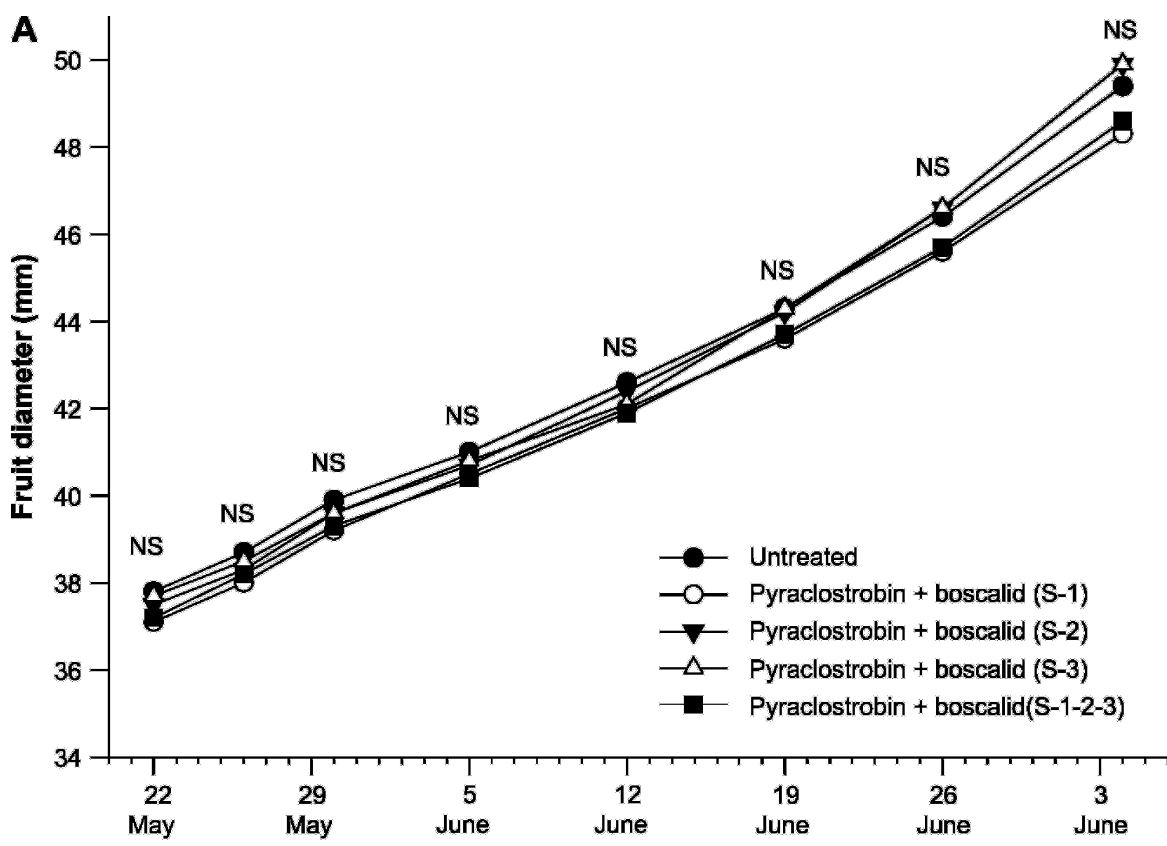

evaluation. For 'O'Henry', 10 slices per replication-treatment (from different fruit) were used on the day of harvest, and after $3 \mathrm{~d}$ of ripening, six more slices from the same six fruit (from the opposite cheek) were used for evaluation. Using the 2,2diphenyl-1-picrylhydrazyl (DPPH) free radical method (Brand-Williams et al., 1995), samples were extracted in methanol to assure a good phenolic representation, as it has been reported that phenolics are the main antioxidant contributors compared with carotenoids and vitamin $\mathrm{C}$ for peaches, nectarines, and plums (Gil et al., 2002). Samples were homogenized using a polytron (Ultra-Turrax TP 18/101 S1; Junke \& Kunkel, Staufen, Germany) and were centrifuged (Sorvall RC5C; Du Pont, Wilmington, DE) for $25 \mathrm{~min}$. The supernatant was analyzed against the standard, Trolox (a water-soluble vitamin E analog), and was reported in micrograms of Trolox equivalents (TE) per gram of tissue.

Data analysis. The fruit size values for each treatment were calculated as the mean of 10 fruit (observations) from each of 10,12 , or 18 trees (replications) for each cultivar and year at each of 9 to 14 sampling dates. The sampling dates were analyzed separately. The fruit size data for each sampling date was subjected to analysis of variance (ANOVA) for a randomized block design using the General Linear Model (GLM) procedure of SAS (version 9.1; SAS Institute, Cary, NC). The scab (Fusicladosporium carpophilum) incidence, red color, background color, firmness, soluble solids, and fruit weight values for each treatment were calculated as the mean of 50 fruit (observations) for scab incidence and red color; 10 fruit for background color, firmness, and soluble solids, and one observation for fruit weight (average of 50 fruit) from each of 10 trees (replications) across two harvest dates for each cultivar and year. These data were subjected to ANOVA for a randomized block design using the GLM procedure of SAS (version 9.1). Each of the harvest dates were considered blocks in the ANOVA.

\section{Results and discussion}

For South Carolinian cultivars Coronet and Contender, there were 
no significant interactions between harvest date and treatments, with few exceptions. Harvest date $x$ treatment interactions were only significant for 'Coronet' in the year 2006 for the background color (chip) $P=$ 0.0049 and 'Contender' for year 2005 for scab $P=0.0477$. After careful examination of the interactions, it was determined that no main effects were masked or distorted by the interaction (data not shown); therefore, the main effects are reported and used in the discussion as a combined data set for each cultivar separately. Fruit size of 'Coronet' and 'Contender' did not differ between the untreated program and the pyraclostrobin + boscalid program in both experimental years, with one exception (Figs. 1 and 2). In 2006, pyraclostrobin + boscalid-treated 'Coronet' peaches were consistently bigger starting from the first evaluation date (24 Apr.) up to the last evaluation date (22 June; Fig. 1B). However, the first seasonal application of the pyraclostrobin + boscalid mixture occurred after the first size evaluation was conducted, indicating that these treatments were not responsible for the size differences. Statistical analysis using the MIXED procedure of SAS indicated that a correction for the pre-existing differences would render differences between treatments as "nonsignificant" at all evaluation times (data not shown).

Fruit diameter was not significantly different between the untreated control and the pyraclostrobin + boscalid treatments for cultivars May Glo (Fig. 3A) and O'Henry (Fig. 3B). A significant difference was detected, however, between the pyraclostrobin + boscalid treatment applied five times after pit hardening (S-1-2-3) and other pyraclostrobin + boscalid treatments (Fig. 3B). Fruit weight determined in 'Coronet' and 'Contender' did not differ between spray programs in both experimental years (Table 1). Fruit weight was also unaffected in the two cultivars growing under California conditions (data not shown). For 'May Glo' and 'O'Henry', there was no significant difference in antioxidant activity, using the DPPH free radical method (Brand-Williams et al., 1995), between any of the treatments (Table 2). We did not observe insect or disease damage on fruit of any of the California orchards.

This finding is in contrast to studies on annual plants such as cereal crops, where azoxystrobin applications increased yield in the absence of disease pressure (Jones and Bryson, 1998; Jørgensen and Nielsen, 1994, 1996; Nielsen and Jørgensen, 1995). The biochemical basis for the "greening effect" has not been thoroughly investigated, but some QoI fungicides, such as kresoxim-methyl, were shown to increase nitrate reductase activity in spinach (Spinacia oleracea) plants (Glaab and Kaiser, 1999) and to decrease ethylene production in wheat leaf discs (Grossman and Retzlaff, 1997). With increased nitrate reductase activity, the plant can use more nitrogen. Because much of a mature peach tree is woody, increased nitrate reductase activity due to QoI fungicide applications is likely restricted to the leaf and limited green twig area. As such, the effect in a mature woody plant may be less compared with wheat, for example, where a much greater area of the plant is photosynthetically active.

Table 1. Influence of pyraclostrobin + boscalid treatments on scab incidence and fruit quality parameters in 'Coronet' and 'Contender' peaches over 2 years $\left(2005\right.$ and 2006). ${ }^{\mathrm{z}}$

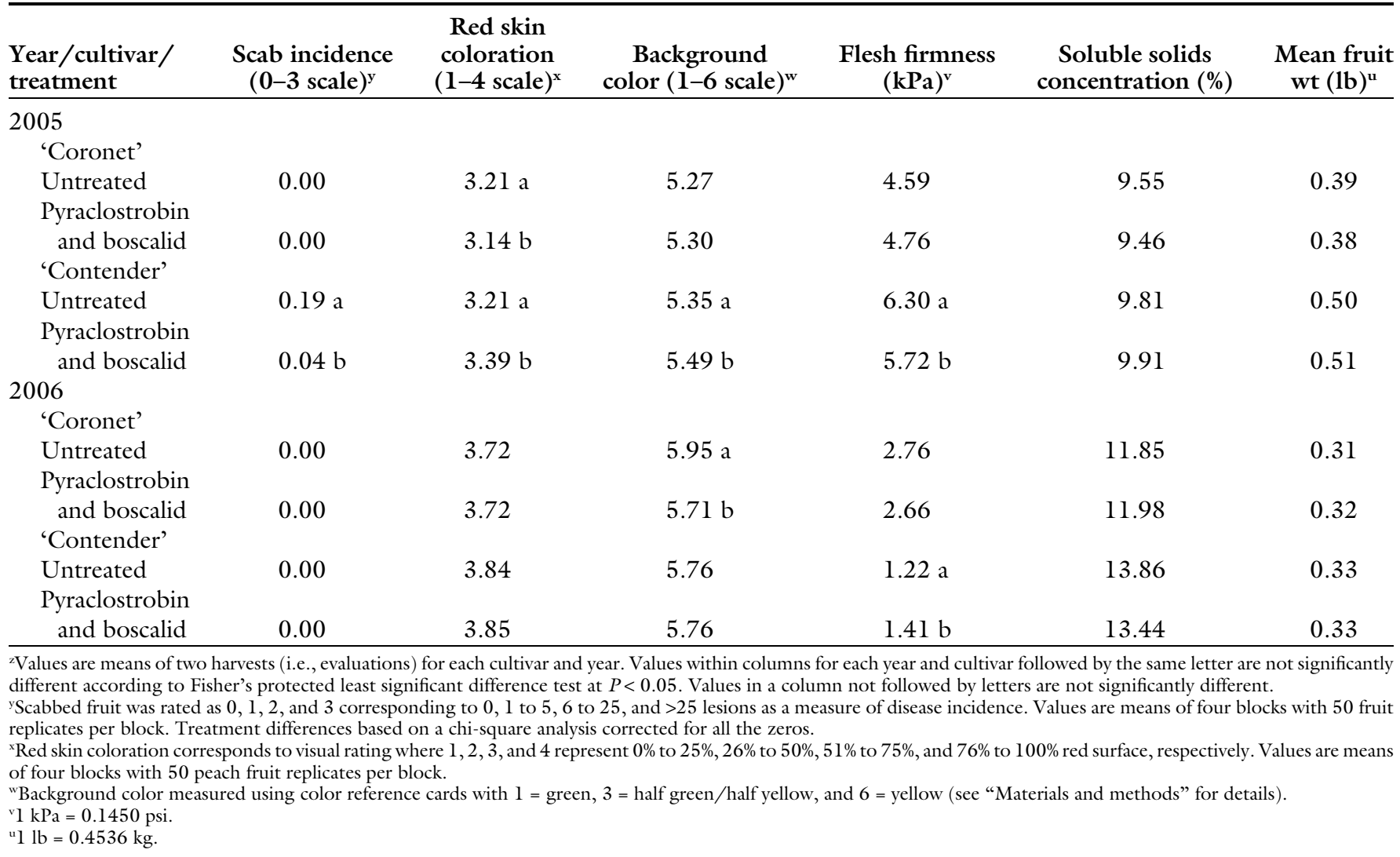


Table 2. Influence of pyraclostrobin + boscalid treatments of 'May Glo' and 'O'Henry' peach on antioxidant activity (AOA) measured at harvest (mature fruit) and after 3 to $5 \mathrm{~d}$ of storage at $68{ }^{\circ} \mathrm{F}\left(20.0{ }^{\circ} \mathrm{C}\right.$ ) (ripe fruit), by the 2,2-diphenyl-1-picrylhydrazyl (DPPH) free radical method

\begin{tabular}{|c|c|c|c|c|}
\hline \multirow[b]{3}{*}{ Treatment/application timing ${ }^{y}$} & \multicolumn{4}{|c|}{$\begin{array}{c}\text { Antioxidants (Trolox equivalents; } \\
\left.\mu_{\text {g. }} \mathrm{g}^{-1} \text { tissue) }\right)^{\mathrm{z}}\end{array}$} \\
\hline & \multicolumn{2}{|c|}{ 'May Glo' } & \multicolumn{2}{|c|}{ 'O'Henry' } \\
\hline & Mature & Ripe & Mature & Ripe \\
\hline Untreated & $432.6 \mathrm{a}$ & $306.0 \mathrm{a}$ & $832.2 \mathrm{a}$ & $1,010.7 \mathrm{a}$ \\
\hline Pyraclostrobin + boscalid $(S-1)$ & - & - & $1,001.9 \mathrm{a}$ & $1,056.4 \mathrm{a}$ \\
\hline Pyraclostrobin + boscalid (S-2) & - & - & $853.2 \mathrm{a}$ & $924.6 \mathrm{a}$ \\
\hline Pyraclostrobin + boscalid $(S-3)$ & $422.0 \mathrm{a}$ & $389.1 \mathrm{a}$ & 820.9 a & $798.2 \mathrm{a}$ \\
\hline Pyraclostrobin + boscalid (S-1-2-3) & - & - & $990.5 \mathrm{a}$ & $878.5 \mathrm{a}$ \\
\hline
\end{tabular}

Alternatively, if the "greening effect" is indeed associated with a delay in leaf senescence, it may not affect peaches in the year of application because peach fruit growth and maturation occurs in advance of leaf senescence. Therefore, the effect of delayed leaf senescence might affect carbohydrate accumulation in woody tissues after harvest. Carryover effects could not be examined in this study because trees at the South Carolina location were re-randomized in experimental year 2. Some studies on fruit found an increase in the percentage of marketable fruit or total yield when QoI fungicides were applied (Ammermann et al., 2000; Heaney and Knight 1994), but the effects coincided with improved disease management. Therefore, it is not clear if in the latter studies the beneficial effects were due to less diseased and therefore healthier plants or due to the "greening effect."

Our study is the first to investigate a possible effect of a QoI fungicide on fruit quality attributes of tree fruit (perennial) in the absence of disease pressure. The "greening effect" of QoI fungicides is commonly believed to be associated with a delay in leaf senescence (Habermeyer et al., 1998; Konradt et al., 1996). In our study, we did not observe greener foliage in pyraclostrobin + boscalidtreated trees, which is consistent with our results on yield and fruit size. Researchers are still debating the underlying cause for the delay in leaf senescence. It has been suggested that the delay in senescence may be due to the inhibition of saprophytes (Smedegaard-Petersen and Tolstrup,
1985), fewer defensive reactions in the plant tissue to plant pathogenic fungi (Bertelsen et al., 2001), or the inhibition of early fungal growth (Godwin et al., 1994).

Fungicides can influence fruit finish, but in this study carried out in two locations, pyraclostrobin + boscalid applications did not appear to have a consistent and commercially relevant impact on this peach fruit quality attribute (Table 1). In one cultivar (Contender) and l year (2005), there were slight, but significant increases in red skin coloration and background color in pyraclostrobin + boscalid-treated peaches (Table 1 ). The lower flesh firmness of these peaches indicated advanced ripening, which explains the improved coloration. Scab pressure was higher that year in 'Contender' peaches, resulting in a higher scab incidence rating in the untreated program compared with the pyraclostrobin + boscalid program. It is possible that this stress factor has caused the premature ripening of the peaches and consequently the advanced coloration. Pyraclostrobin + boscalid applied on early, mid, and late season peach and nectarines growing under California conditions did not improve fruit quality attributes (data not shown). While pyraclostrobin + boscalid did not impact fruit quality in our study, other fungicides have been shown to influence fruit maturity and coloration. Preharvest applications of captan, for example, were shown to improve skin finish and cause more intense fruit color and earlier fruit ripening in apple (Carlone, 1958). On peach, sulfur-treated fruit appeared to have less color and eye appeal and matured 3 to $4 \mathrm{~d}$ later when compared with fruit treated with carbon-based fungicides (Drake, 1984; Scherm and Savelle, 2001). In a recent multiyear and multicultivar study, however, no impact of micronized or nonmicronized sulfur on peach fruit quality was detected (Schnabel et al., 2007).

\section{Conclusions}

The collective results for South Carolina and California suggest that seasonal applications of a pyraclostrobin + boscalid mixture formulated as Pristine do not improve same-year fruit quality or yield of peach fruit. Carryover effects into the next season were not investigated.

\section{Literature cited}

Adaskaveg, J.E., H. Förster, W.D. Gubler, B.L. Teviotdale, and D.F. Thompson. 2004. Reduced risk fungicides: A new way of managing brown rot and other fungal diseases of stone fruit crops. California Agr. 59:109-114.

Ammermann, E., G. Lorenz, K. Schelberger, B. Mueller, R. Kirstgen, and $\mathrm{H}$. Sauter. 2000. BAS 500 F: The new broadspectrum strobilurin fungicide. Brighton Crop Protection Conference: Pests and Diseases. British Crop Protection Council, Farnham, UK. p. 541-548.

Becker, W.F., G. Von Jagow, T. Anke, and W. Steglich. 1981. Oudemansin, strobilurin A, strobilurin B and myxothiazol: New inhibitors of the $b_{1}$ segment of the respiratory chain with an E- $\beta$-methoxyacrylate system as common structural element. FEBS Lett. 132:329-333.

Bertelsen, J.R., R. de Neergaard, and V. Smedegaard-Petersen. 2001. Fungicidal effect of azoxystrobin and epoxiconazole on phyllosphere fungi, senescence and yield of winter wheat. Plant Pathol. 50:190-205.

Brand-Williams, W., M.E. Cuvelier, and C. Berset. 1995. Use of a free radical method to evaluate antioxidant activity. Lebensmittel Wissenschaft und Technologie 28:25-30.

Brannen, P.M., D. Horton, B. Bellinger, and D. Ritchie. 2005. 2005 Southeastern peach, nectarine and plum pest management and culture guide. University of Georgia, Athens.

Carlone, R. 1958. Side effects of a noncopper fungicide on apples. Frutticoltura 20:43-52.

Crisosto, C.H., R.S. Johnson, J.G. Luza, and G.M. Crisosto. 1994. Irrigation 
regimes affect fruit soluble solids concentration and rate of water loss of ' $O$ 'Henry' peaches. HortScience 29:1169-1171.

Delwiche, M.J. and R.A. Baumgardner. 1985. Ground color as a peach maturity index. J. Amer. Soc. Hort. Sci. 110:53-57.

Drake, C.R. 1984. Efficacy of various fungicides and fungicide combinations for control of peach disease, 1983. Fungicide Nematicide Tests 39:40.

Gil, M.I., A. Tomas-Barberan, B. HessPierce, and A.A. Kader. 2002. Antioxidant capacities, phenolic compounds, carotenoids, and vitamin C contents of nectarines, peach, and plum cultivars from California. J. Agr. Food Chem. 50:49764982 .

Glaab, J. and W.M. Kaiser. 1999. Increased nitrate reductase activity in leaf tissue after application of the fungicide kresoxim-methyl. Planta 207:442-448.

Godwin, J.R., D.W. Bartlett, J.M. Clough, A.R.A. Godfrey, E.G. Harrison, and S. Maund. 2000. Picoxystrobin: A new strobilurin fungicide for use on cereals. Brighton Crop Protection Conference: Pests and Diseases. British Crop Protection Council, Farnham, UK. p. 533-540.

Godwin, J.R., J.E. Young, and C.A. Hart. 1994. ICIA 5504: Effects on development of cereal pathogens. Brighton Crop Protection Conference: Pests and Diseases. British Crop Protection Council, Farnham, UK. p. 253-258.

Grossman, K. and G. Retzlaff. 1997. Bioregulatory effects of the fungicidal strobilurin kresoxy-methyl in wheat (Triticum aestivum). Pestic. Sci. 50:11-20.
Habermeyer, J., M. Gerhard, and V. Zinkernagel. 1998. The impact of strobilurins on the plant physiology of wheat. 7th Intl. Conf. Plant Pathol. British Society of Plant Pathology, Edinburgh, UK.

Harrison, S. and E. Tedford. 1999. Quadris: A novel fungicide for disease control in rice. Second Temperate Rice Conf. Sacramento, CA. p. 289-294.

Heaney, S.P. and S.C. Knight. 1994. ICIA5504: A novel broad-spectrum systemic fungicide for use in fruit, nut and horticultural crops. Brighton Crop Protection Conference: Pests and Diseases. Sacramento, CA. p. 509-516.

Jones, D.R. and R.J. Bryson. 1998. Physiological effects of strobilurins and plant activators in relation to yield of winter wheat. Project Rpt. No. 164. Home Grown Cereals Authority, London.

Jørgensen, L.N. and B.J. Nielsen. 1994. Results from field trials 1994. Control of diseases in cereals. Statens Planteavlsforsøg, Roskilde, Denmark.

Jørgensen, L.N. and B.J. Nielsen. 1996. Results from field trials 1996. Control of diseases in cereals. Statens Planteavlsforsøg, Roskilde, Denmark.

Konradt, M., E.M. Kappes, M. Hiemer, and H.H. Petersen. 1996. Amistar-ein Strobilurin zur Bekaempfung von Getreidekrankheiten. Gesunde Pflanzen 48: 126-134.

Margot, P., F. Huggenberger, J. Amrein, and B. Weiss. 1998. CGA279202: A new broad-spectrum strobilurin fungicide. British Crop Protection Council, Farnham, UK. p. 375-382.
Nielsen, B.J. and L.N. Jørgensen. 1995. Results from field trials 1995. Control of diseases in cereals. Statens Planteavlsforsøg, Roskilde, Denmark.

Noon, R.A. 1997. Azoxystrobin and cereal grain quality. British Crop Protection Council and the Association Nationale de Protection des Plantes Conference. University of Kent, Canterbury, UK. p. 467472.

Scherm, H. and A.T. Savelle. 2001. Control of peach scab with reduced midseason fungicide programs. Plant Dis. 85:706712 .

Schnabel, G., D.R. Layne, and I.J. Holb. 2007. Micronized and nonmicronized sulphur applications control peach scab equally well with negligible differences in fruit quality. Ann. Appl. Biol. 150:131139.

Siviero, P. and A. Azzaro. 2001. Centenimento dei marciumi in post-raccolta su pomodoro da mensa in serra. L'Informatore Agrario 1:59.

Smedegaard-Petersen, V. and K. Tolstrup. 1985. The limiting effect of disease resistance on yield. Annu. Rev. Phytopathol. 23:475-490.

Stevenson, W.R., R.L. James, R.E. Rand, and L.A. Flak. 1999. Wisconsin's field experience with azoxystrobin fungicide for control of early blight on potato. Phytopathology 89:S75. (Abstr.).

Von Jagow, G. and T.A. Link. 1986. Use of specific inhibitors on the mitochondrial $b c_{1}$ complex. Methods Enzymol. 126: 253-271. 